\title{
Metabolic Benefit of Bulls Being Fed Moringa Leaves Twigs and Branches as a Major Concentrate Ingredient
}

\section{OPEN ACCESS}

Edited by:

James Levi Klotz,

Agricultural Research Service (USDA),

United States

Reviewed by:

Ruangyote Pilajun,

Ubon Ratchathani University, Thailand

Peter Erickson,

University of New Hampshire,

United States

*Correspondence:

Nani Gopal Das

nani.gd@hotmail.com

tThese authors have contributed equally to this work and share the first authorship

Specialty section: This article was submitted to

Animal Nutrition,

a section of the journal

Frontiers in Animal Science

Received: 21 May 2021

Accepted: 06 July 2021

Published: 10 August 2021

Citation:

Sultana N, Das NG, Kabir MA,

Deb GK and Islam MT (2021) Metabolic Benefit of Bulls Being Fed Moringa Leaves Twigs and Branches as a Major Concentrate Ingredient.

Front. Anim. Sci. 2:712919.

doi: 10.3389/fanim.2021.712919

\author{
Nasrin Sultana ${ }^{1 \dagger}$, Nani Gopal Das ${ }^{1 * t}$, Md Ahsanul Kabir ${ }^{2}$, Gautam Kumar Deb ${ }^{2}$ and \\ Md Tarequl Islam ${ }^{1}$
}

${ }^{1}$ Animal Production Research Division, Bangladesh Livestock Research Institute, Savar Union, Bangladesh, ${ }^{2}$ Biotechnology Division, Bangladesh Livestock Research Institute, Savar Union, Bangladesh

The study was conducted to investigate nutrient metabolism and semen quality of bulls fed with moringa (Moringa oleifera) leaves, twigs, and branches as a major concentrate ingredient. Twenty-one Red Chittagong bulls of about $204( \pm 50) \mathrm{kg}$ initial live weight (LW) were randomly divided into three equal LW groups. They were fed maize silage as a basal feedstuff for 65 days with the supplementation of concentrate mixtures at $1 \%$ of LW, consisting of either 0,25 , or $50 \%$ moringa mash on a fresh basis. Moringa mash was a sun-dried ground preparation of leaves, twigs, and branches of moringa. The results indicated that different levels of moringa in concentrate mixtures $(0,25$, and $50 \%)$ did not change daily DM intake, digestibility, and LW gain of bulls $(p>0.05)$. However, increasing dietary moringa (up to $203 \mathrm{~g} / \mathrm{kg}$ DM) significantly decreased production cost of methane $\left(\mathrm{CH}_{4}\right)$ (methane emission [kg/kg gain] = 1.6422-[0.0059 $\times$ moringa intake, $\left.\mathrm{g} / \mathrm{kg} \mathrm{DM}], n=12, R^{2}=0.384, P=0.032\right)$ in a similar metabolizable energy intake level $(0.21 \pm 0.01 \mathrm{MJ} / \mathrm{kg} \mathrm{LW})$. Also, higher dietary moringa significantly reduced urinary nitrogen loss (urinary nitrogen [\% digested nitrogen] $=43.0-0.069 \times$ moringa intake [g/kg DM]; $\left.R^{2}=0.3712, P=0.034\right)$. Thus, increasing moringa by $1 \mathrm{~g} / \mathrm{kg}$ DM decreased $\mathrm{CH}_{4}$ emission by $6 \mathrm{~g} / \mathrm{kg}$ gain and absorbed nitrogen loss by $0.069 \%$. Also, progressive motility of sperm increased significantly $(33.0,51.0$, and $60.1 \%$, respectively; $p=0.03$ ) in bulls fed with concentrate mixtures containing moringa at 0,25 , or $50 \%$. It may be concluded that feeding moringa mash at $203 \mathrm{~g} / \mathrm{kg}$ DM may decrease energy loss as methane and urinary nitrogen loss without impacting the production of beef cattle. Feeding moringa mash to beef cattle may abate dietary energy and nitrogen loss and consequently decrease the environmental pollution.

Keywords: bioenergetics, feed efficiency, methane conversion factor, moringa, nutrient metabolism

\section{INTRODUCTION}

Dietary nutrient loss, particularly energy, and nitrogen, from beef cattle feeding may determine the level of the environmental impact of production. For example, anaerobic fermentation of feedstuff in the rumen of Zebu beef cattle in tropical developing countries fed with low-quality crop residues and byproducts incurs about $4.8-13.7 \%$ of dietary gross energy (GE) loss as methane $\left(\mathrm{CH}_{4}\right)$ production (Kaewpila and Sommart, 2016). The amount of volatile solids (VS) in manure, as determined by the manure energy content (fecal and urinary energy loss) and dietary organic matter (OM) level, may undergo anaerobic conditions and emit $\mathrm{CH}_{4}$ at varying rates according 
to different manure management systems in different environmental temperatures (IPCC, 2019). Similarly, manure nitrogen may undergo microbial decomposition and emit $\mathrm{N}_{2} \mathrm{O}$ by nitrification and denitrification processes. Also, organic manure nitrogen (urea in mammals) tends to be mineralized as ammonium nitrogen and converts to $\mathrm{NH}_{3}$. Emissions of such greenhouse gases $\left(\mathrm{CH}_{4}\right.$ and $\left.\mathrm{N}_{2} \mathrm{O}\right)$ from farm animal production are a global concern for their substantial climate change impacts. Global livestock sector emission contributes to about $18 \%$ of anthropogenic greenhouse gas annually, leading to global warming (Gerber et al., 2013). In Bangladesh, livestock greenhouse gas emission was estimated to be about $70 \times 10^{3}$ $\mathrm{Gg} /$ year carbon dioxide equivalent (Das et al., 2020).

Mitigation of greenhouse gas emission from livestock entails increasing dietary efficiency. Increasing dietary nutrient utilization in animal production (particularly energy and protein) may minimize their unproductive wastes and subsequent $\mathrm{CH}_{4}$ and $\mathrm{N}_{2} \mathrm{O}$ emissions to the environment. There may be lower need for conversion of dietary GE to $\mathrm{CH}_{4}$ when a diet with more digestible ingredients is fed to cattle (Kurihara et al., 1999; Liu et al., 2017). Therefore, dietary strategies were reported to be effective in reducing enteric $\mathrm{CH}_{4}$ emissions in ruminants (Kebreab et al., 2010; Gastelen et al., 2019; Min et al., 2020). Regarding this, Benchaar et al. (2001) quantified that dietary manipulation may reduce up to $40 \%$ of enteric $\mathrm{CH}_{4}$ emissions. Knapp et al. (2014) registered that improving feeds, feeding, and nutritional approaches may reduce up to $15 \%$ of enteric $\mathrm{CH}_{4}$ emissions in dairy cattle production. An efficient diet may also produce less manure nitrogen and thus less anaerobic fermentation or aerobic decomposition of nitrogen to emit $\mathrm{CH}_{4}$, $\mathrm{N}_{2} \mathrm{O}$, and $\mathrm{NH}_{3}$ into the air.

Efforts to reduce dietary energy loss as $\mathrm{CH}_{4}$ include supplementation of diet with fats $(<5 \%)$ (Johnson and Johnson, 1995), organic acids (Castillo et al., 2004), plant secondary metabolites (Beauchemin et al., 2008), essential oils (Tamminga et al., 2007), and probiotics, ionophores, antibiotics, and so on ( $\mathrm{Su}$ and Chen, 2020). In this context, leaves, foliage, and pods of moringa (Moringa oleifera), which are rich in secondary metabolites (Premi and Sharma, 2017; Su and Chen, 2020) and have the potential to reduce rumen $\mathrm{CH}_{4}$ production and gain in nutrient metabolism and animal production, were found promising. Dong et al. (2019) found that supplementing dairy cattle diet with 6\% moringa (rachises and twigs) changed the composition and diversity of fecal methanogens (lower count of Methanobrevibacter ruminantium, a methanogenic bacteria), indicating modification of rumen microbiomes and producing less enteric $\mathrm{CH}_{4}$. Soliva et al. (2005) found $17 \%$ reduction of enteric $\mathrm{CH}_{4}$ emission in vitro and reported moringa leaves to be an inhibitor of methanogens and as an alternative to antibiotic feed additives of cattle. Another in vitro study registered up to $50 \%$ reduction of rumen $\mathrm{CH}_{4}$ by replacing soybean meal with moringa leaf meal (Elghandour et al., 2017). A linear reduction of rumen $\mathrm{CH}_{4}$ was registered in cattle when supplementation of moringa seeds in the concentrate mixture was increased up to $40 \%$ (Lins et al., 2019).

In addition to $\mathrm{CH}_{4}$ emission reduction, improvement in digestion and utilization of nutrients of concentrate mixtures (in vitro) was found when conventional ingredients were replaced with moringa leaves at 25-50\% level (Nouala et al., 2006). Greater utilization of dietary nutrients was reported when $75 \%$ of berseem clover diet of Nubian goats was replaced with moringa leaves (Kholif et al., 2018). Consequently, supplementing moringa leaves and their extracts in diets increased the quality of goat meat (Qwele et al., 2013), presumably because of its abundant secondary metabolites, vitamins, flavonoids, phenols, and carotenoids (Su and Chen, 2020). Considering biomass yield, $\mathrm{CH}_{4}$ emission reduction efficiency, animal production efficiency, and cost-benefit ratio, moringa was ranked on top of common forages in Bangladesh (Huque et al., 2017).

Along with growth performances, carotenoids, and vitamin E in moringa leaf (Qwele et al., 2013; Su and Chen, 2020) may help promote the reproduction of animals and maintain various physiological functions of bones, epithelial tissues, visceral, and mucosal epithelial secretions, and cellular immunity by protecting cells from harmful free radicals. Greater litter size, birth weight, and survival in mice were registered when a normal diet was supplemented with 4\% moringa leaf (Zeng et al., 2019). When rice straw was replaced with $3 \%$ moringa leaves from the diet of Bali bulls $(0.15 \%$ LW), the libido and progressive sperm motility was found to increase significantly (Syarifuddin et al., 2017). Therefore, the objectives of the study were to investigate the efficiency of dietary nutrient utilization and semen quality of bulls fed with moringa leaves, twigs, and branches as a major ingredient in the concentrate.

\section{MATERIALS AND METHODS}

\section{Study Location and Ethical Statement}

The study was conducted at Cattle Research Farm of Bangladesh Livestock Research Institute (BLRI), Savar Dhaka, Bangladesh (latitude $23.89^{\circ} \mathrm{N}$, longitude $90.27^{\circ} \mathrm{E}$ ). During the feeding trial in bulls (September-November, 2019), the average air temperature and humidity were $28( \pm 3)^{\circ} \mathrm{C}$ and $73( \pm 6) \%$, respectively. The care and management of experimental bulls were in accordance with the procedures of Curtis and Nimz (1988) and approved by the Annual Research Evaluation Committee of BLRI (2019).

\section{Production of Moringa Mash}

Moringa mash was produced by collecting leaves, twigs, and branches $(2-3 \mathrm{~cm})$ from a previously established plot at BLRI Cattle Research Farm, Savar, Dhaka in May-June 2019. The collected biomass was mechanically chopped into pieces (3$5 \mathrm{~cm}$ ) and dried in sun for about 24-32 h (3-4 days). The dried biomass was ground in an electric grinder by passing through a 3-mm sieve, and the moringa mash thus produced was stored in plastic drums until feeding to animals. The stored moringa mash was used to produce different concentrate mixtures according to their fresh ingredient composition (Table 2), similar to conventional ones.

\section{Ensiling of Maize}

The maize (Zea mays) was harvested at 85 days of cultivation in April 2019, chopped into $2-3 \mathrm{~cm}$ pieces, and ensiled in a pit at the BLRI Cattle Research Farm. No additives and fermenters were 
TABLE 1 | Composition of diets.

\begin{tabular}{|c|c|c|c|c|c|}
\hline Concentrate ingredient ( $\%$ fresh) & $\mathrm{CM}_{0}$ & $\mathrm{CM}_{25}$ & $\mathrm{CM}_{50}$ & Moringa mash & Maize silage \\
\hline Wheat bran & 37 & 23 & 20 & - & - \\
\hline Ground maize & 30 & 24 & 7 & - & - \\
\hline Moringa & 0 & 25 & 50 & - & - \\
\hline Common salt & 1 & 1 & 1 & - & - \\
\hline \multicolumn{6}{|l|}{ Chemical composition (\% DM) } \\
\hline DM (\% fresh) & 90.4 & 91.2 & 90.1 & 87.6 & 22.3 \\
\hline OM & 91.0 & 91.2 & 91.2 & 89.9 & 90.5 \\
\hline $\mathrm{CP}$ & 19.6 & 19.5 & 19.4 & 13.4 & 8.0 \\
\hline NDF & 34.4 & 34.5 & 35.7 & 44.6 & 50.3 \\
\hline
\end{tabular}

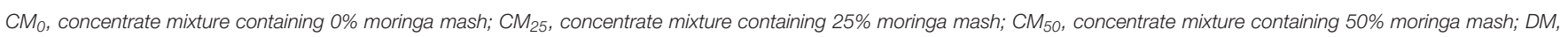
dry matter; OM, organic matter; $C P$, crude protein; NDF, neutral detergent fiber; ADF, acid detergent fiber; GE, gross energy.

TABLE 2 | Nutrient intake and live weight changes in bulls.

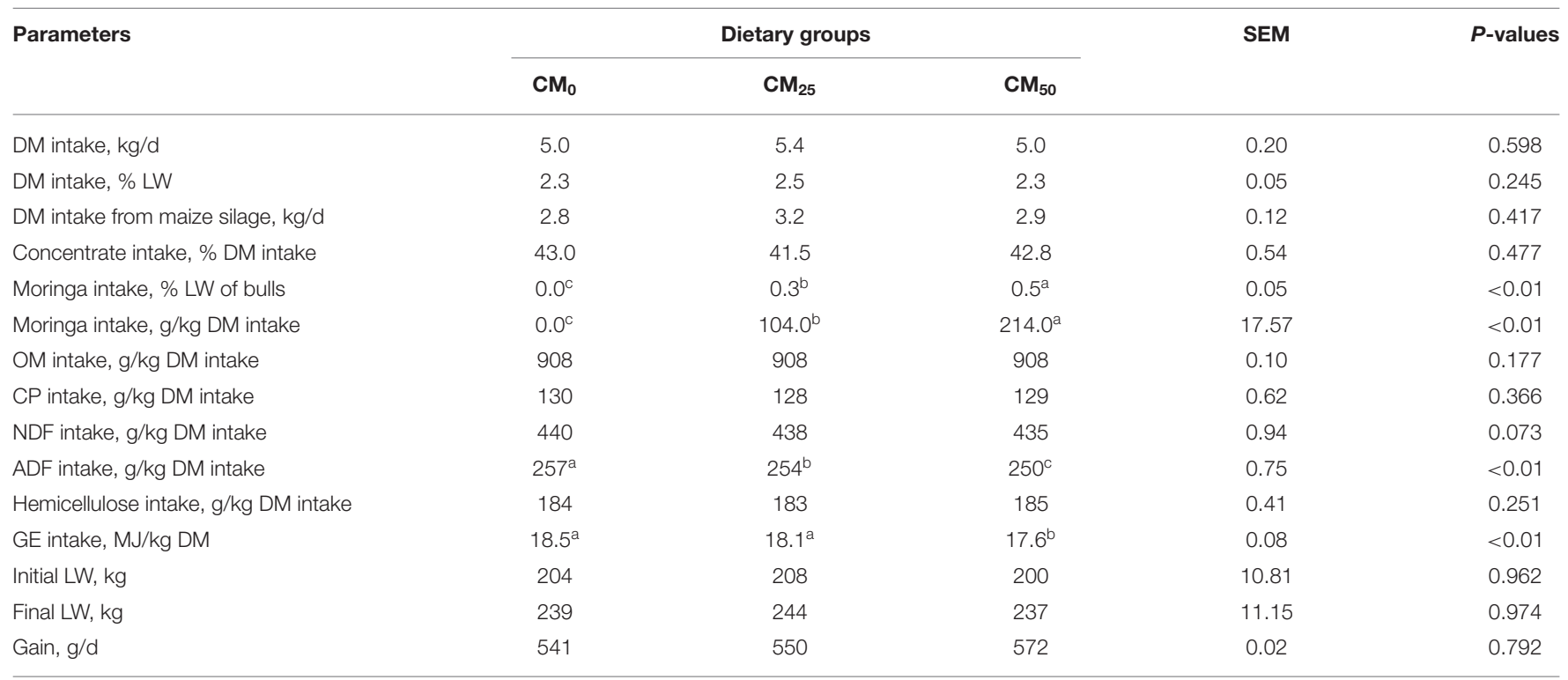

$C M_{0}$, concentrate mixture containing 0\% moringa mash; $C_{25}$, concentrate mixture containing $25 \%$ moringa mash; $C M_{50}$, concentrate mixture containing $50 \%$ moringa mash; $L W$, live weight; $D M$, dry matter; $O M$, organic matter; $C P$, crude protein; NDF, neutral detergent fiber; $A D F$, acid detergent fiber; GE, gross energy.

SEM, standard error of mean; $P<0.05$, significant.

${ }^{a b c}$ means with different superscripts within same raw are significantly different.

used in the ensiling process. The silage was fed to trial bulls as a basal feedstuff to appetite in September-November 2019.

\section{Selection and Management of Bulls}

Twenty-one bulls of about 25-32 months of age were selected from a large Red Chittagong Cattle (RCC) herd at BLRI, Savar, Dhaka, and weighed at $700 \mathrm{~h}$ before morning feeding. They were housed individually in concrete stalls $\left(1.0 \times 2.5 \mathrm{~m}^{2}\right)$ where there was $24 \mathrm{~h}$ supply of adequate clean drinking water. They were fed maize silage with a supplementation of a conventional concentrate mixture $\left(\mathrm{CM}_{0}\right.$, Table 1$)$, representing $1 \%$ live weight (LW) for a 15-day adjustment period. Maize silage was weighed and supplied in two equal parts at 900 and $1,600 \mathrm{~h}$ daily. About $20 \%$ extra maize silage was supplied than the intake of the previous day to ensure ad libitum intake. The concentrate mixture was fed about $30 \mathrm{~min}$ before feeding silage, and no refusals of concentrate mixtures were found. The daily supply and refusal of maize silage and intake of concentrate mixture 
were recorded. During adjustment, they were dewormed by drenching with an anthelmintic drug (Trilev-Vet ${ }^{\circledR}$ Bolus, Square Pharmaceuticals Limited, Bangladesh) according to prescribed doses. After adjustment, they were weighed (initial LW $204 \pm$ $50 \mathrm{~kg}$ ) at $700 \mathrm{~h}$ before morning feeding, divided into three equal LW groups, and fed experimental diets for 65 days.

\section{Feeding Management of Bulls}

After the adjustment period, bulls were weighed fortnightly before morning feeding $(700 \mathrm{~h})$ to adjust their daily concentrate mixture allowances $(1 \% \mathrm{LW})$. During the whole feeding trial (after adjustment), $\mathrm{CM}_{0}$ concentrate mixture was supplemented to bulls of the control group, whereas concentrate mixtures containing either 25 or $50 \%$ of moringa mash $\left(\mathrm{CM}_{25}\right.$ and $\mathrm{CM}_{50}$, respectively; Table 1) were supplemented to bulls of other groups. All the concentrate mixtures were iso-nitrogenous (Table 1). The concentrate mixtures were produced weekly according to their ingredient composition, and a representative portion of samples (about $250 \mathrm{~g}$ ) were kept in air-tight sample bags and stored in a deep freeze $\left(-20^{\circ} \mathrm{C}\right)$ until analysis. The ingredient composition of concentrate mixtures and chemical composition of maize silage and concentrate mixtures are presented in Table $\mathbf{1 .}$

\section{Metabolism Trial}

On the 51st day of the feeding trial, four bulls from each group were weighed and transferred to metabolic crats individually to study digestibility and metabolism of nutrients. Before the collection period (7 days), bulls were given a 7 -day adjustment period to feeding and management in metabolic crats. The supply of feeds and refusals were recorded as described earlier. The overnight fasted LW of bulls were taken before and at the end of the collection period. The feces and urine samples were weighed and recorded at $700 \mathrm{~h}$ daily. Feces were collected in a plastic bin with a lid. Feces collected every $24 \mathrm{~h}$ were weighed, mixed thoroughly, and about $10 \%$ of samples were kept in properly labeled air-tight sample bottles. A portion of the fresh sample (about $20 \mathrm{gm}$ ) was used in determining DM, whereas the remaining was kept frozen $\left(-20^{\circ} \mathrm{C}\right)$ for further laboratory analysis. The urine was collected into a plastic bucket containing $200 \mathrm{ml}$ of $20 \% \mathrm{H}_{2} \mathrm{SO}_{4}(\mathrm{v} / \mathrm{v})$, weighed, diluted to $20 \mathrm{~L}$ by adding fresh clean tap water, kept in properly labeled sample bottles $(100 \mathrm{ml})$, and stored in a deep freeze $\left(-20^{\circ} \mathrm{C}\right)$ until analysis. In the end, samples of feedst offered, refusals, and feces were thawed to room temperature; aliquots for each bull were pooled and mixed thoroughly. The subsamples (about $2.5 \mathrm{~kg}$ ) were dried in a forced air oven at $60^{\circ} \mathrm{C}$ for $72 \mathrm{~h}$ and ground by passing through a $1-\mathrm{mm}$ sieve to prepare them for further laboratory analysis. The urine samples of each bull were mixed in a bucket and composited, and a subsample (about $100 \mathrm{ml}$ ) was taken in a properly labeled sample bottle and sent to the laboratory for analysis.

\section{Chemical Analysis of Samples}

The dry matter (DM), ash, and crude protein (CP) or nitrogen of feeds, concentrate mixtures, feed refusals, and feces were determined according to methods described by the AOAC (2006). Briefly, the methods of determining DM, ash, and CP (or nitrogen) were methods $934.01,934.05$, and 981.10 , respectively. The neutral detergent fiber (NDF) and acid detergent fiber (ADF) were determined following the methods of Van Soest et al. (1991). The GE contents of feeds, refusal, and feces were determined in a Shimadzu auto-calculating bomb calorimeter (Shimadzu CA-4PJ, Shimadzu Corporation, Japan).

\section{Calculations}

The GE intake was calculated as the difference between GE supplied and refused in orts. The digestible energy (DE) intake was calculated as the difference between GE intake and fecal energy (FE) outgo. Urinary energy (UE) excretion was calculated according to Ramin and Huhtanen (2013) by the following equation:

$$
\begin{array}{r}
\mathrm{UE}(\mathrm{MJ} / \mathrm{d})=-2.71+0.028 \times \mathrm{CP}(\mathrm{g} / \mathrm{kg} \mathrm{DM}) \\
+0.589 \times \mathrm{DMI}(\mathrm{kg} / \mathrm{d}) .
\end{array}
$$

The enteric methane conversion factor ( $Y_{\mathrm{m}}, \% \mathrm{GE}$ intake) was calculated according to the following equation (Jaurena et al., 2015):

$\mathrm{Y}_{\mathrm{m}}=2-0.243 \times \mathrm{DMI}+0.0059 \times \mathrm{NDF}+0.0057 \times \mathrm{DDM}$, where $Y_{\mathrm{m}}$, is the methane conversion factor (\%GE intake); DMI, DM intake (kg/d); NDF, NDF of the diet (g/kg DM); and DMD, DM digestibility $(\mathrm{g} / \mathrm{kg})$. From the $Y_{\mathrm{m}}$ value and GE intake, GE loss as methane emission was calculated. The methane emission factor was calculated by the following equation (IPCC, 2019), using the $Y_{\mathrm{m}}$ values of the present study:

$\mathrm{EF}=\frac{\mathrm{GEI} \times\left(\frac{\mathrm{Y}_{\mathrm{m}}}{100}\right) \times 365}{55.65}, \mathrm{~kg}$ methane/animal/year, where $\mathrm{EF}$, enteric methane emission factor ( $\mathrm{kg} /$ animal/year); GEI, GE intake (MJ/d); 55.65, energy content of methane $(\mathrm{MJ} / \mathrm{kg}$ methane). The UE and energy loss as methane was subtracted from $\mathrm{DE}$ intake to estimate metabolizable energy (ME) intake. The amount of VS in manure was calculated by calculating manure energy loss (FE and UE outgo) and ash fraction of dietary DM intake of bulls (ASH) according to IPCC (2019) (Equation 10.24). The fasting heat production was estimated according to the following equation (Blaxter, 1962):

Fasting Heat $=1.15 \times 0.53 \times\left(\frac{\mathrm{LW}}{1.08}\right)^{0.67} \mathrm{MJ} / \mathrm{d}$. The retained energy $(\mathrm{RE})$ was calculated by subtracting heat production energy from ME. The ME for maintenance $\left(\mathrm{ME}_{\mathrm{m}}\right)$ and partial efficiency of utilization of $\mathrm{ME}$ for gain $\left(\mathrm{k}_{\mathrm{g}}\right)$ was calculated by constructing a linear regression of $\mathrm{RE}\left(\mathrm{kJ} / \mathrm{kgW}^{0.75}\right)$ as a function of ME intake $\left(\mathrm{kJ} / \mathrm{kgW}^{0.07}\right)$ according to a model $\mathrm{RE}=\beta_{0}+\left(\beta_{1} \times \mathrm{ME}\right)$; where $\beta_{0}$ is intercept and $\beta_{1}$ is the slope which represents the efficiency of gain $\left(\mathrm{k}_{\mathrm{g}}\right)$. When retained energy is zero, ME intake represents the maintenance level of $\mathrm{ME}\left(\mathrm{ME}_{\mathrm{m}}\right)$. Metabolizable energy for gain was the difference between retained energy and $\mathrm{ME}_{\mathrm{m}}$.

The nitrogen balance (NB) was calculated by the following equation: $\mathrm{NB}=[($ nitrogen supply - nitrogen refused in orts $)-$ (fecal nitrogen + urinary nitrogen)]. The total nitrogen outgo (fecal and urinary) was converted to nitrogen excretion rate (nitrogen, $\mathrm{kg} / 1,000 \mathrm{~kg} \mathrm{LW} / \mathrm{d}$ ).

\section{Semen Quality of Bulls}

After completion of a 65-day feeding trial, four bulls of similar age (28-32 months) from each group were managed in the 
TABLE 3 | Digestibility of nutrients.

\begin{tabular}{|c|c|c|c|c|c|}
\hline \multirow[t]{2}{*}{ Digestibility (\%) } & \multicolumn{3}{|c|}{ Dietary groups } & \multirow[t]{2}{*}{ SEM } & \multirow[t]{2}{*}{$P$-values } \\
\hline & $\mathrm{CM}_{0}$ & $\mathrm{CM}_{25}$ & $\mathrm{CM}_{50}$ & & \\
\hline DM & 61.5 & 62.5 & 64.8 & 0.73 & 0.353 \\
\hline $\mathrm{OM}$ & 63.3 & 64.5 & 66.5 & 0.76 & 0.217 \\
\hline $\mathrm{CP}$ & 67.0 & 70.0 & 70.3 & 0.70 & 0.277 \\
\hline NDF & 40.3 & 42.5 & 49.5 & 1.59 & 0.274 \\
\hline ADF & 36.3 & 34.3 & 39.3 & 1.40 & 0.270 \\
\hline Hemicellulose & 46.0 & 54.0 & 62.5 & 2.92 & 0.120 \\
\hline DE (\% GE) & 67.6 & 65.3 & 68.0 & 0.63 & 0.051 \\
\hline
\end{tabular}

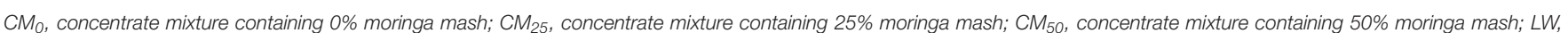
live weight; DM, dry matter; OM, organic matter; CP, crude protein; NDF, neutral detergent fiber; ADF, acid detergent fiber; GE, gross energy.

SEM, standard error of mean; $p<0.05$, significant.

previous feeding and management regime for the next 15 days. They were given the training to jump on dummy bull, ejaculate semen, and subsequent collection using artificial vagina three times in a 2-day interval. Then, semen volume and evaluation were done by collecting semen every 2 days with a 2-day interval at the end. Handling of semen samples was done according to Susilawati (2017) by collecting semen using artificial vaginas. Initially, semen volume and color were recorded, and finally, semen quality was evaluated by using Computer Assisted Semen Analyzer (CASA) with Sperm VisionTM software (version 3.7.5).

\section{Statistical Analysis}

The study was conducted in a completely randomized design with three dietary treatments having sevenbulls as experimental units in each. Data were analyzed according to the general linear model procedures using IBM SPSS statistical software (version 20 for windows, SPSS Inc., Chicago, IL, USA). The mathematical model of the procedure is: $Y_{i j}=\mu+T_{i}+\varepsilon_{i j}$; where $Y_{i j}=$ observed data, $\mu=$ overall mean, $T_{i}=$ effect of dietary treatment, and $\varepsilon_{i j}=$ error. Means were separated by conducting Duncan's multiple range test and presented by calculating SEM. Significant differences between means were declared at $p<0.05$, and a tendency of difference was declared at $p<0.10$.

\section{RESULTS}

\section{Nutrient Intake and LW Changes in Bulls}

The dietary DM intake of bulls was not different (Table 2; $P>0.05)$ when moringa mash was added to up to 214 $\mathrm{g} / \mathrm{kg} \mathrm{DM}$, replacing convectional concentrates. The DM intake represented about $2.3-2.5 \%$ of LW of bulls, wherein the concentrate represented about 41-43\%. Intake of OM, CP, NDF, and hemicellulose of bulls was also similar $(P>0.05)$. However, intake of $\mathrm{ADF}$ and GE from diets decreased with the increase of moringa mash in the concentrates $(P<0.05)$. As a consequence of feeding moringa at 104-214 g/kg DM (Table 2), final LW and daily gain of bulls were not affected $(P>0.05)$.

\section{Digestibility of Nutrients}

Addition of moringa up to $203 \mathrm{~g} / \mathrm{kg} \mathrm{DM}$ as a concentrate ingredient did not affect the digestibility of DM and nutrients in diets significantly (Table $3 ; p>0.05$ ). A tendency of greater $\mathrm{DE}(\% \mathrm{GE})$ was found with the increase of moringa in diet ( $p$ $=0.051)$.

\section{Metabolism of Nutrients}

Dietary supplementation of moringa up to $203 \mathrm{~g} / \mathrm{kg} \mathrm{DM}$ did not exert any significant effect $(P>0.05)$ on the metabolism of energy and nitrogen in bulls (Table 4). However, nitrogen balance showed a tendency to increase $(P=0.082)$ with the addition of moringa in diets (up to $203 \mathrm{~g} / \mathrm{kg} \mathrm{DM}$ ). All bulls were in positive energy and nitrogen balance during the study.

A relationship between dietary moringa level, ME intake, and calculated methane emission (Figure 1) during the metabolic study period showed that, with the increase of moringa in diet $(0-203 \mathrm{~g} / \mathrm{kg} \mathrm{DM})$, the $\mathrm{CH}_{4}$ cost of beef cattle production decreases significantly (from 2,962 to $427 \mathrm{CH}_{4}$ g/kg gain; $n=12$, $\left.R^{2}=0.384, P=0.032\right)$ in a similar ME intake level $(0.21 \pm$ $0.01 \mathrm{MJ} / \mathrm{kg} \mathrm{LW}$ ), suggesting that moringa may help increase the efficiency of utilization of retained energy for growth and reduce the environmental cost of beef cattle production in a similar dietary plane of energy. The regression equation (methane emission, $\mathrm{kg} / \mathrm{kg}$ gain $=1.6422-[0.0059 \times$ moringa intake, $\mathrm{g} / \mathrm{kg}$ $\mathrm{DM}]$ ) suggests that, if moringa intake is increased by $1 \mathrm{~g} / \mathrm{kg} \mathrm{DM}$ in diet, methane emission may be decreased by about $6 \mathrm{~g} / \mathrm{kg}$ gain, presumably because of better retained energy utilization for growth.

Also, a significant power relationship between LW gain $(\mathrm{g} / \mathrm{d})$ and $\mathrm{CH}_{4}$ emission (g/kg gain) shows that, with the increase of daily gain, methane cost of beef cattle production decreases significantly $\left(n=12, R^{2}=0.9687, P<0.01\right.$ ) (Figure 2 ). The relationship explains that, by increasing $1 \mathrm{~g} / \mathrm{kg}$ of LW gain of bulls (from 35 to $246 \mathrm{~g} / \mathrm{d}$ ), methane cost of gain reduces by about 13.6 $\mathrm{g} / \mathrm{kg}$ gain (from 3,325 to 457 ).

A linear regression of retained energy on ME intake of bulls $\left(\mathrm{kJ} / \mathrm{kgW}^{0.75}\right.$; Figure 3$)$ is significant $\left(n=12, R^{2}=0.9253, P\right.$ $<0.01)$. The relationship illustrates that $\mathrm{ME}$ requirement for 
TABLE 4 | Metabolism of nutrients.

\begin{tabular}{|c|c|c|c|c|c|}
\hline \multirow[t]{2}{*}{ Parameters } & \multicolumn{3}{|c|}{ Dietary groups } & \multirow[t]{2}{*}{ SEM } & \multirow[t]{2}{*}{$P$-values } \\
\hline & $\mathrm{CM}_{0}$ & $\mathrm{CM}_{25}$ & $\mathrm{CM}_{50}$ & & \\
\hline GE intake, MJ/d & 97 & 109 & 100 & 3.77 & 0.463 \\
\hline FE loss, MJ/d & 32 & 38 & 32 & 1.63 & 0.288 \\
\hline DE intake, MJ/d & 65 & 71 & 68 & 2.27 & 0.581 \\
\hline UE, MJ/d & 3.8 & 4.4 & 4.0 & 0.13 & 0.259 \\
\hline Volatile solids, kg/d & 1.9 & 2.3 & 2.0 & 0.10 & 0.314 \\
\hline Volatile solids, kg/1,000 kg LW/d & 7.5 & 8.0 & 7.4 & 0.25 & 0.630 \\
\hline Methane energy loss, MJ/d & 6.1 & 6.8 & 6.3 & 0.20 & 0.390 \\
\hline Methane conversion factor $\left(\mathrm{Y}_{\mathrm{m}}\right)$ & 6.3 & 6.2 & 6.3 & 0.05 & 0.619 \\
\hline Methane emission, kg/kg gain & 1.8 & 0.9 & 0.7 & 0.24 & 0.138 \\
\hline Methane conversion factor $\left(D_{m}\right)$ & 9.4 & 9.5 & 9.3 & 0.09 & 0.711 \\
\hline Metabolizable energy intake, MJ/d & 55 & 60 & 57 & 2.01 & 0.634 \\
\hline Metabolizability (Q) & 0.6 & 0.6 & 0.6 & 0.01 & 0.100 \\
\hline Energy efficiency, ME/DE & 0.85 & 0.84 & 0.85 & 0.001 & 0.274 \\
\hline Metabolizable energy for maintenance $\left(\mathrm{ME}_{\mathrm{m}}\right), \mathrm{MJ} / \mathrm{d}$ & 22.8 & 24.8 & 23.3 & 0.85 & 0.650 \\
\hline Metabolizable energy for gain $\left(\mathrm{ME}_{\mathrm{g}}\right)$, MJ/d & 32.5 & 35.5 & 34.5 & 1.12 & 0.584 \\
\hline Feeding level & 2.5 & 2.5 & 2.5 & 0.01 & 0.767 \\
\hline Heat energy, MJ/day & 24 & 26 & 24 & 0.85 & 0.650 \\
\hline Retained energy (NE), MJ/d & 31 & 34 & 34 & 1.10 & 0.570 \\
\hline Retained energy, \% GE intake & 32 & 31 & 33 & 0.45 & 0.234 \\
\hline $\mathrm{N}$ intake, g/d & 102.0 & 121.3 & 110.3 & 4.75 & 0.280 \\
\hline$N$ in feces, $g / d$ & 34.3 & 36.0 & 33.3 & 1.82 & 0.857 \\
\hline $\mathrm{N}$ in urine, $\mathrm{g} / \mathrm{d}$ & 30.0 & 27.5 & 24.0 & 1.41 & 0.231 \\
\hline $\mathrm{N}$ balance, $\mathrm{g} / \mathrm{d}$ & 38.0 & 57.8 & 53.0 & 3.88 & 0.082 \\
\hline $\mathrm{N}$ excretion rate in manure, $\mathrm{kg} / 1,000 \mathrm{~kg} \mathrm{LW} / \mathrm{d}$ & 0.25 & 0.23 & 0.22 & 0.01 & 0.470 \\
\hline
\end{tabular}

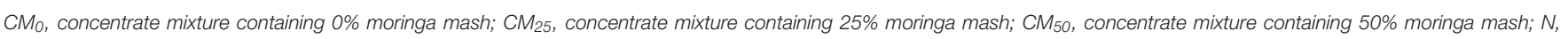
nitrogen; GE, gross energy; $D E$, digestible energy; $M E$, metabolizable energy; UE, urinary energy.

SEM, standard error of mean; $p<0.05$, significant.

maintenance of RCC bulls was $350 \mathrm{~kJ} / \mathrm{kgW}^{0.75}$ at a feeding level of $2.5( \pm 0.05)$ (Table 4).

The linear regression analysis shows a significant reduction of urinary nitrogen loss with increasing dietary moringa level, even when digested nitrogen intake was increasing (Figure 4), implying greater efficiency of absorbed nitrogen utilization. According to the relation, even increasing one unit of dietary moringa $(\mathrm{g} / \mathrm{kg} \mathrm{DM})$ reduced urinary loss of absorbed nitrogen by $0.069 \%$ (urinary nitrogen [\% digested nitrogen] $=43.004$ $0.0688 \times$ moringa intake $\left.[\mathrm{g} / \mathrm{kg} \mathrm{DM}] ; R^{2}=0.3712, P=0.034\right)$.

\section{Semen Quality of Bulls}

Supplementing moringa to diets increased progressive motility of bull sperm significantly $(P=0.026$; Table 5$)$. It also exerted a tendency to decrease coil-tailed abnormal sperm $(P=0.111)$.

\section{DISCUSSION}

\section{Nutrient Intake and LW Changes in Bulls}

The present study showed that the addition of moringa of up to $214 \mathrm{~g} / \mathrm{kg} \mathrm{DM}$ of diet did not affect the dietary intake of bulls. This might be due to similar NDF intake of bulls fed from different diets $(440,438$, and $435 \mathrm{~g} / \mathrm{kg} \mathrm{DM}$, respectively in
$\mathrm{CM}_{0}, \mathrm{CM}_{25}$, and $\mathrm{CM}_{50}$ groups; $p=0.073$, Table 2). The DM intake of RC bulls (2.3-2.5\%; Table 2) was similar to the findings of Roy et al. (2016) who fed sole maize silage to BLRI Cattle Breed-1 (BCB 1) bulls for 75 days and reported about $2.5 \%$ of LW. Even, replacing a maize silage diet of cows with moringa leaf postulated similar DM intake (Zeng et al., 2018). The CP intake of bulls (about 650-691 g/d; calculated from Table 2) of 273 ( \pm 49$) \mathrm{kg}$ LW experiencing 541-572 g/d gain was consistent with the recommended requirements of BSTI (2008). The CP requirements of a $250-300 \mathrm{~kg}$ bull with $500 \mathrm{~g} / \mathrm{d}$ gain is about 623-678 g/d (BSTI, 2008).

\section{Digestibility of Nutrients}

Intake of similar NDF (435 to $440 \mathrm{~g} / \mathrm{kg} \mathrm{DM}$ ) and ADF (250 to $257 \mathrm{~g} / \mathrm{kg} \mathrm{DM}$ ) from different diets (Table 2) might result in their similar digestibility. Digestibility of diet DM (62-65\%; Table 3) was higher than the values reported for sole maize silage (60\%) by Roy et al. (2016). Supplementation of concentrate at $43 \%$ (Table 2) might be responsible for higher digestibility. The higher trend of digestibility of DM and other nutrients (Table 3) in moringa-supplemented diets (104 and $214 \mathrm{~g} / \mathrm{kg} \mathrm{DM;}$ Table 2) agrees with the findings of Nouala et al. (2006), who reported higher in vitro true digestibility of concentrate mixtures 


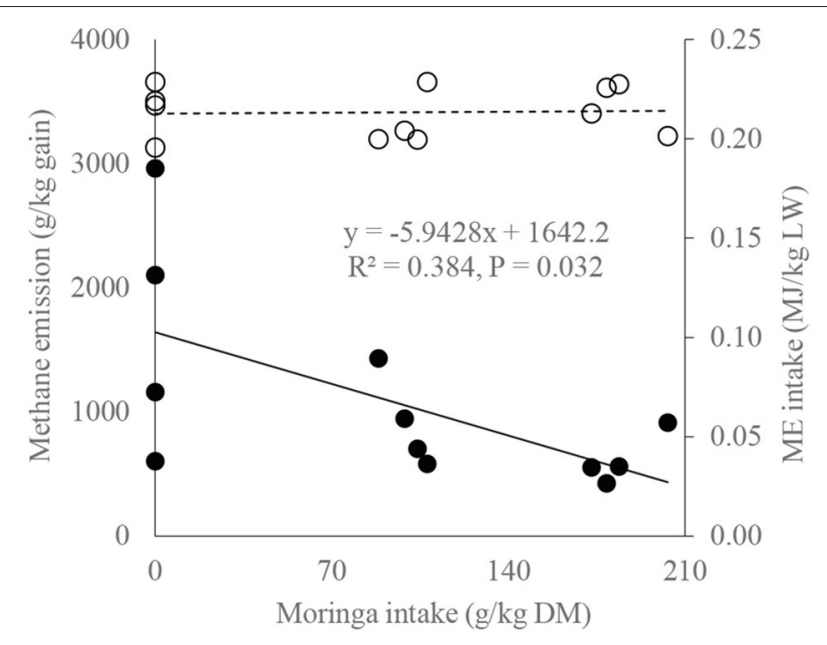

FIGURE 1 | Methane emission and metabolizable energy (ME) intake of bulls as a function of moringa intake [solid line and bold markers represent methane emission ( $/ \mathrm{kg}$ gain), and dotted line with circle markers represent ME intake $(\mathrm{MJ} / \mathrm{kg} \mathrm{LW})]$.

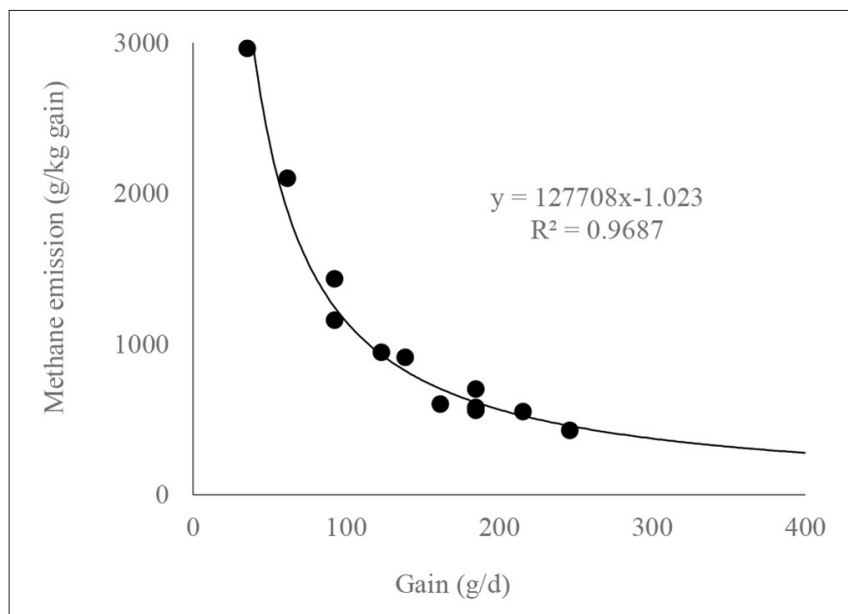

FIGURE 2 | Methane emission (g/kg gain) as a function of live weight gain of bulls $(g / d)$.

containing $25 \%$ or $50 \%$ moringa leaves. Also, the addition of moringa at different levels might be responsible for changes in the digestibility of other nutrients. For example, feeding of moringa foliage to cows at $264 \mathrm{~g} / \mathrm{kg} \mathrm{DM}$ of the diet reported significantly greater digestibility of $\mathrm{DM}, \mathrm{OM}$, and other cell wall contents (Sánchez et al., 2006). The level of moringa in the diet of bulls represented up to $203 \mathrm{~g} / \mathrm{kg}$ DM during the digestibility study.

\section{Metabolism of Nutrients}

The study represents fecal energy loss of $32-35 \%$ GE intake (Table 4; calculated), which corroborates with the findings of da Fonseca et al. (2019), who reported about 33.6\% fecal GE loss in bulls fed with tropical forages. The estimated urinary energy loss represents $3.9-4.0 \%$ of GE intake (Table 4 ; calculated), which is similar to the default values ( $4 \%$ in forage-based diet) reported by

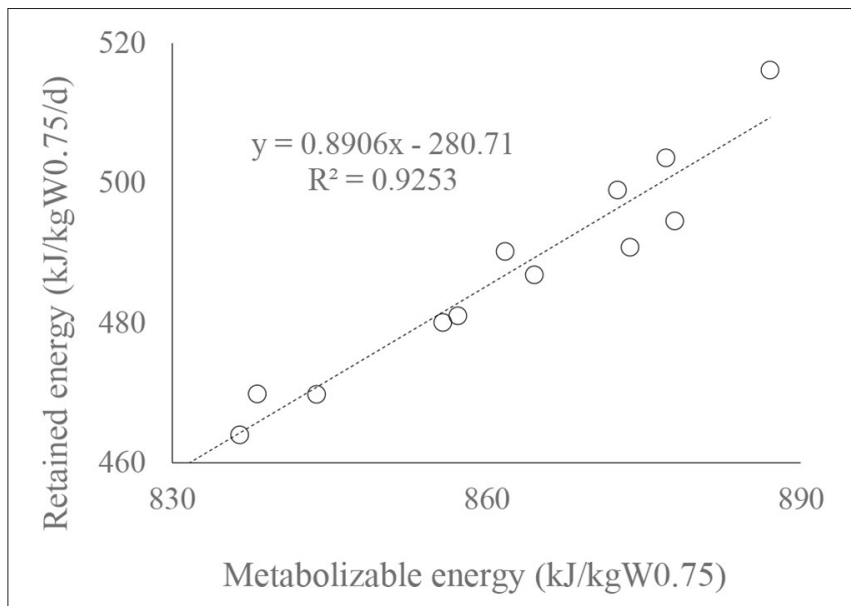

FIGURE 3 | Fit plots for retained energy $\left(\mathrm{kJ} / \mathrm{kgW}^{0.75}\right)$ as a function of ME $\left(\mathrm{KJ} / \mathrm{kgW}^{0.75}\right)$ intake of Red Chittagong bulls.

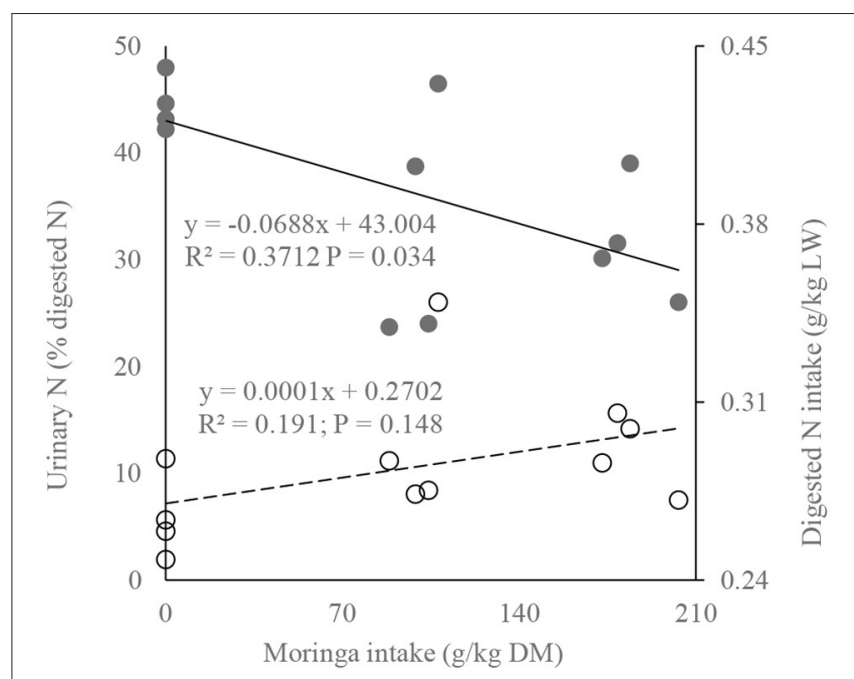

FIGURE 4 | Fit plots of digested nitrogen and urinary nitrogen as a function of dietary moringa level [solid line and bold markers represent urinary nitrogen (\% digested nitrogen), whereas dotted line and circle markers represent digested nitrogen intake $(\mathrm{g} / \mathrm{kg} \mathrm{LW})$.

IPCC (2019). The amount of VS in manure $(7.4-8.0 \mathrm{~kg} / 1,000 \mathrm{~kg}$ LW) of this study is about $38 \%$ less than recommended default values of IPCC (2019) (12.0-13.5 kg/1,000 kg LW; Table $10.13 \mathrm{~A}[\mathrm{new}])$ for beef cattle in Indian subcontinent. Methane conversion factor $\left(Y_{\mathrm{m}}, \%\right.$ GE intake) (6.2-6.3; Table 4) was similar to the recommended values of IPCC (2019). The average ME intake of bulls ( $237 \pm 49 \mathrm{~kg}$; 55-60 MJ/d; Table 4) with LW gain of $143( \pm 64) \mathrm{g} / \mathrm{d}$ during the metabolic study was higher than the recommended level (39 MJ/d; BSTI, 2008). The energy efficiency (ME/DE) of the study is higher than the value reported by NRC (2000) (0.80) but within the range (0.84-0.88) reported by Chaokaur et al. (2015). About $1 \%$ higher energy retention (\% GE intake) was found in bulls fed with a diet containing 214 $\mathrm{g} / \mathrm{kg}$ DM compared with control $(P=0.234$; Table 4$)$. Nitrogen 
TABLE 5 | Reproductive performances of bulls.

\begin{tabular}{|c|c|c|c|c|c|}
\hline \multirow[t]{2}{*}{ Parameters } & \multicolumn{3}{|c|}{ Dietary groups } & \multirow[t]{2}{*}{ SEM } & \multirow[t]{2}{*}{$P$-values } \\
\hline & $\mathrm{CM}_{0}$ & $\mathrm{CM}_{25}$ & $\mathrm{CM}_{50}$ & & \\
\hline Semen volume (ml) & 3.5 & 3.8 & 3.8 & 0.19 & 0.840 \\
\hline Total count (million/ml) & 245.0 & 384.0 & 210.0 & 42.18 & 0.289 \\
\hline \multicolumn{6}{|l|}{ Morphology } \\
\hline Normal sperm (\% total count) & 83.0 & 82.0 & 84.0 & 0.59 & 0.534 \\
\hline Band tail (\% total count) & 9.9 & 9.3 & 4.9 & 1.51 & 0.364 \\
\hline Coil tail (\% total count) & 4.2 & 2.3 & 1.6 & 0.57 & 0.111 \\
\hline \multicolumn{6}{|l|}{ Motility } \\
\hline Static (\% total count) & 42.0 & 38.0 & 23.0 & 4.87 & 0.234 \\
\hline Motile (\% total count) & 58.0 & 62.0 & 77.0 & 4.87 & 0.234 \\
\hline (a) Progressive motile (\% total count) & $33.0^{\mathrm{b}}$ & $51.0^{\mathrm{ab}}$ & $60.1^{\mathrm{a}}$ & 5.19 & 0.026 \\
\hline (b) Slow motile (\% total count) & 1.3 & 1.1 & 0.5 & 0.46 & 0.838 \\
\hline
\end{tabular}

$\mathrm{CM}_{0}$, concentrate mixture containing 0\% moringa mash; $\mathrm{CM}_{25}$, concentrate mixture containing $25 \%$ moringa mash; $C M_{50}$, concentrate mixture containing 50\% moringa mash.

SEM, standard error of mean.

$p<0.05$, significant.

${ }^{a b}$ means with different superscripts within same raw are significantly different.

excretion rate of bulls $(0.22-0.25 \mathrm{~kg} / 1,000 \mathrm{~kg} \mathrm{LW} / \mathrm{d})$ were lower than the default IPCC values for the beef cattle in Indian subcontinent [0.40-0.63 kg/1,000 kg LW/d; (IPCC, 2019)].

Lower energy cost of LW gain by increasing moringa in the diet in a similar plane of dietary energy level (Figure 1) might be due to the manipulation of ruminal methanogenic communities caused by different antioxidants and secondary metabolites in moringa, as registered in previous studies (Soliva et al., 2005; Dong et al., 2019). The regression between LW gain and $\mathrm{CH}_{4}$ emission (g/kg gain Figure 2) corroborates the findings of Kurihara et al. (1999), who reported that $\mathrm{CH}_{4}$ production $\left(\mathrm{CH}_{4}, \mathrm{~g} / \mathrm{kg} \mathrm{LW}\right.$ gain) decreases curvilinearly with the increase of daily LW gain of bulls. Such relationships might also be consisted in increasing the digestibility tendency of energy (Table 3), as Hristov et al. (2013) postulated decreased enteric $\mathrm{CH}_{4}$ with increasing digestibility. The $M E_{m}$ requirement of $R C$ bulls $\left(\mathrm{ME}_{\mathrm{m}}\right.$ $=350 \mathrm{~kJ} / \mathrm{kgW}^{0.75}$; Figure 3) at 2.5 feeding level is well below the value recommended by Kearl $\left(1982 ; 493 \mathrm{~kJ} / \mathrm{kgW}^{0.75}\right)$ but close to the value of Liang and Young $\left(1995 ; 335 \mathrm{~kJ} / \mathrm{kgW}^{0.75}\right.$ for growing Kedah Kelantan bulls) and Subepang et al. (2019; $388 \mathrm{~kJ} / \mathrm{kgW}^{0.75}$ for Thai native cattle), at 1.1-2.0 feeding level. Unproductive dietary nitrogen loss in urine increases linearly with increasing dietary nitrogen intake (Kebreab et al., 2010), and such nitrogen losses are associated with emitting $\mathrm{N}_{2} \mathrm{O}$ and $\mathrm{NH}_{3}$ as a byproduct of aerobic or anaerobic microbial metabolism (Liu et al., 2017), causing environmental pollution. In this study (Figure 4), it is evident that, without increasing dietary nitrogen intake, reduction of urinary nitrogen loss may be possible by supplementing the diet with moringa at $203 \mathrm{~g} / \mathrm{kg}$ DM. The impact of feeding moringa to increase LW gain in bulls is also evident in this study (Table 2) where the daily gain is $31 \mathrm{~g} / \mathrm{d}$ higher in the moringa diet (214 g/kg DM) compared with control.

\section{Semen Quality of Bulls}

Higher progressive motility of sperms from bulls fed with moringa mash (25\% of $50 \%$ of concentrate mixtures) might be due to certain nutritional constituents of moringa mash. Eghbali et al. (2010) and Princewill et al. (2015) reported that higher plasma content of $\mathrm{Ca}$ and $\mathrm{P}$ results in greater bovine sperm motility. Other nutrients that contribute to increased total sperm motility and progressive motility include arginine, carnitine, $\mathrm{Zn}$, vitamin B12, vitamin $\mathrm{C}$, vitamin $\mathrm{E}$, glutathione, selenium, and Coenzyme Q-10 Begum et al. (2009). Moringa was reported to be a great source of all these nutrients (Su and Chen, 2020). Feeding moringa mash might increase the plasma level of these nutrients, which might cause better progressive sperm motility. Similar findings were also reported in Bali bulls and buffalo (Syarifuddin et al., 2017 and Wafa et al., 2017, respectively).

\section{CONCLUSION}

The results of the study indicate that replacement of conventional concentrate ingredient (particularly ground maize, soybean meal, and wheat bran) with up to $50 \%$ of mixtures with moringa mash may not affect DM intake and LW gain of bulls. However, when the inclusion of moringa represented $203 \mathrm{~g} / \mathrm{kg}$ DM of the diet of a bull, it may significantly increase ME utilization and reduce urinary nitrogen loss, even when the dietary level of energy and nitrogen is similar. When dietary moringa addition is increased by $1 \mathrm{~g} / \mathrm{kg} \mathrm{DM}$, calculated methane emission is decreased by 6 $\mathrm{g} / \mathrm{kg}$ gain, with simultaneous absorbed nitrogen loss reduction by $0.069 \%$. Thus, increasing the efficiency of dietary energy and nitrogen utilization in bulls may be achieved by adding moringa mash to concentrate mixtures at $50 \%$ and fed at $1 \%$ LW. Reduction of dietary energy and nitrogen loss of bulls may also help reduce subsequent environmental pollution.

\section{DATA AVAILABILITY STATEMENT}

The original contributions presented in the study are included in the article, further inquiries can be directed to the corresponding authors. 


\section{ETHICS STATEMENT}

The animal study was reviewed and approved by Annual Research Evaluation Committee of Bangladesh Livestock Research Institute, 2019.

\section{AUTHOR CONTRIBUTIONS}

ND and NS conceived and designed the study, conducted trial and laboratory works, interpreted the data, and drafted

\section{REFERENCES}

AOAC (2006). Association of Official Analytical Chemists. Official Methods of Analysis of AOAC International. Gaithersburg, MD: AOAC.

Beauchemin, K. A., Kreuzer, M., O'Mara, F., and McAllister, T. A. (2008). Nutritional management for enteric methane abatement: a review. Aust. J. Exp. Agric. 48, 21-27. doi: 10.1071/EA07199

Begum, H., Moniruddin, A., and Nahar, K. (2009). Environmental and nutritional aspect in male infertility. J. Med. 10, 16-19. doi: 10.3329/jom.v10i1.1997

Benchaar, C., Pomar, C., and Chiquette, J. (2001). Evaluation of dietary strategies to reduce methane production in ruminants: a modelling approach. Can. J. Anim. Sci. 81, 563-574. doi: 10.4141/A00-119

Blaxter, K. L. (1962). "The utilization of the energy of food by ruminants," in Energy Metabolism of Farm Animals (Wageningen: Pudoc), 211.

BSTI (2008). Feeds and Feeding Standards for Farm Animals and Pets. (Dhaka: Bangladesh Standards and Testing Institution, 116-A Maan Bhaban, Tejgaon Industrial Area).

Castillo, C., Benedito, J. L., Mendez, J., Pereira, V., Lopez-Alonso, M., Miranda, M., et al. (2004). Organic acids as a substitute for monensin in diets for beef cattle. Anim. Feed Sci. Technol. 115, 101-116. doi: 10.1016/j.anifeedsci.2004.02.001

Chaokaur, A., Nishida, T., Phaowphaisal, I., and Sommart, K. (2015). Effects of feeding level on methane emissions and energy utilization of Brahman cattle in the tropics. Agric. Ecosyst. Environ. 99, 225-230. doi: 10.1016/j.agee.2014.09.014

Curtis, S. E., and Nimz, C. K. (1988). Guide for the Care and Use of Agricultural Animals in Agricultural Research and Teaching. (Champaign, IL: Consortium for Developing a Guide for the Care and Use of Agricultural Animals in Agricultural Research and Teaching).

da Fonseca, M. P., Borges, A. L., Carvalho, P., Hd,. A., e Silva, R. R., et al. (2019). Energy partitioning in cattle fed diets based on tropical forage with the inclusion of antibiotic additives. PLOS ONE. 14:e0211565. doi: 10.1371/journal.pone. 0211565

Das, N. G., Sarker, N. R., and Haque, M. N. (2020). An estimation of greenhouse gas emission from livestock in Bangladesh. J. Adv. Vet. Anim. Res. 7, 133-140. doi: 10.5455 /javar.2020.g402

Dong, D., Zhang, T., and Diao, Q. (2019). Effect of dietary supplementation of moringa oleifera on the production performance and fecal methanogenic community of lactating dairy cows. Animals 9:262. doi: 10.3390/ani9050262

Eghbali, M., Alavi-Shoushtari, S. M., Asri-Rezaei, S., and Ansari, M. H. K. (2010). Calcium, magnesium and total antioxidant capacity (TAC) in seminal plasma of water buffalo (Bubalus bubalis) bulls and their relationships with semen characteristics. Vet. Res. Forum. 1, 12-20.

Elghandour, M. M. Y., Vallejo, L. H., Salem, A. Z. M., Mellado, M., Camacho, L. M., Cipriano, M., et al. (2017). Moringa oleifera leaf meal as an environmental friendly protein source for ruminants: biomethane and carbon dioxide production, and fermentation characteristics. J. Clean. Produc. 165, 1229-38. doi: 10.1016/j.jclepro.2017.07.151

Gastelen, S., Dijkstra, J., and Bannink, A. (2019). Are dietary strategies to mitigate enteric methane emission equally effective across dairy cattle, beef cattle, and sheep? J. Dairy Sci. 102, 6109-6130. doi: 10.3168/jds.2018-15785

Gerber, P. J., Steinfeld, H., Henderson, B., Mottet, A., Opio, C., Dijkman, J., et al. (2013). Tackling climate change through livestock-a global assessment of emissions and mitigation opportunities. Rome, Italy: Food and Agriculture Organization of the United Nations (FAO). and finalized the manuscript. MK and GD were involved in semen evaluation, data analysis, and drafting of manuscripts. MI was involved in the preparation and analysis of feeding trial samples.

\section{FUNDING}

The work was funded by Bangladesh Livestock Research Institute, Dhaka 1341- Bangladesh.
Hristov, A. N., Oh, J., Lee, C., Meinen, R., Montes, F., Ott, T., et al. (2013). Mitigation of Greenhouse Gas Emissions in Livestock Production-A Review of Technical Options for Non- $\mathrm{CO}_{2}$ Emissions; FAO Animal Production and Health Paper. Rome, QC: Food and Agriculture Organization of the United Nations.

Huque, K. S., Roy, B. K., and Das, N. G. (2017). Biometrical ranking of fodder crops for sustainable livestock and clean air production. Asian J. Agric. Food Sci. 5, 134-143.

IPCC (2019). Refinements to the 2006 Guidelines for National Greenhouse Gas Inventories. Cambridge, ML: Intergovernmental Panel on Climate change (IPCC). Available online at: https://www.ipcc-nggip.iges.or.jp/public/2006gl/ pdf/4_Volume4/V4_10_Ch10_Livestock.pdf (accessed May 9, 2020).

Jaurena, G., Cantet, J. M., Arroquy, J. I., Palladino, R. A., Wawrzkiewicz, M., and Colombatto, D. (2015). Prediction of the Ym factor for livestock from on-farm accessible data. Livest. Sci. 177, 52-62. doi: 10.1016/j.livsci.2015.04.009

Johnson, K. A., and Johnson, D. E. (1995). Methane emissions from cattle. J. Anim. Sci. 73, 2483-2492. doi: 10.2527/1995.7382483x

Kaewpila, C., and Sommart, K. (2016). Development of methane conversion factor models for Zebu beef cattle fed low-quality crop residues and by-products in tropical regions. Ecol. Environ. 6, 7422-7432. doi: 10.1002/ece3.2500

Kearl, L. C. (1982). Nutrient Requirements of Ruminants in Developing Countries Longan, Utah: International Feedstuffs Institute, Utah State University.

Kebreab, E., Strathe, A., Fadel, J., Moraes, L., and France, J. (2010). Impact of dietary manipulation on nutrient flows and greenhouse gas emissions in cattle. Revista Brasileira de Zootecnia. 39, 458-464. doi: 10.1590/S1516-35982010001300050

Kholif, A. E., Gouda, G. A., Olafadehan, O. A., and Abdo, M. M. (2018). Effects of replacement of Moringa oleifera for berseem clover in the diets of Nubian goats on feed utilization, and milk yield, composition and fatty acid profile. Animal 12, 964-972. doi: 10.1017/S1751731117002336

Knapp, J. R., Laur, G. L., Vadas, P. A., Weiss, W. P., and Tricarico, J. M. (2014). Invited review: Enteric methane in dairy cattle production: quantifying the opportunities and impact of reducing emissions. J. Dairy Sci. 97, 3231-3261. doi: $10.3168 /$ jds.2013-7234

Kurihara, M., Magner, T., Hunter, R. A., and McCrabb, G. J. (1999). Methane production and energy partition of cattle in the tropics. Br. J. Nutri. 81, 227-234 doi: $10.1017 /$ S0007114599000422

Liang, J. B., and Young, B. A. (1995). Comparative energetic efficiencies of male Malaysian cattle and buffalo. Livestock Production Science. 41, 19-27. doi: 10.1016/0301-6226(94)00032-3

Lins, T. O. J. D. A., Terry, S. A., Silva, R. R., Pereira, L. G. R., Jancewicz, L. J., He, M. L., et al. (2019). Effects of the inclusion of Moringa oleifera seed on rumen fermentation and methane production in a beef cattle diet using the rumen simulation technique (Rusitec). Animal 13, 283-291. doi: $10.1017 /$ S1751731118001428

Liu, Z., Liu, Y., Murphy, J. P., and Maghirang, R. (2017). Ammonia and methane emission factors from cattle operations expressed as losses of dietary nutrients or energy. Agriculture 7, 1-12. doi: 10.3390/agriculture7030016

Min, B. R., Solaiman, S., Waldrip, H. M., Parker, D., Todd, R. W., and Brauer, D. (2020). Dietary mitigation of enteric methane emissions from ruminants: a review of plant tannin mitigation options. Anim. Nutri. 6, 231-246. doi: 10.1016/j.aninu.2020.05.002

Nouala, F. S., Akinbamijo, O. O., Adewumi, A., Hoffman, E., Muetzel, S., and Becker, K. (2006). The influence of Moringa oleifera leaves as 
substitute to conventional concentrate on the in vitro gas production and digestibility of groundnut hay. Livestock Res. Rural Develop. 18:121. doi: 10.10054/rrd.org/lrrd18/9/noua18121.htm

NRC (2000). Nutrient requirements of beef cattle, 7th revised. ed. National Academy Press, Washington, DC. 2000.

Premi, M., and Sharma, H. K. (2017). Effect of extraction conditions on the bioactive compounds from Moringa oleifera (PKM 1) seeds and their identification using LC-MS. J. Food Measure. Characteriz. 11, 213-225. doi: 10.1007/s11694-016-9388-y

Princewill, O. I., Uchenna, A. E., Charles, O. I., and Uwaezuoke, I. M. (2015). Interactions between dietary miner-als and reproduction in farm animal. Glob. J. Anim. Scien. Res. 3, 524-535.

Qwele, K., Hugo, A., Oyedemi, S. O., Moyo, B., Masika, P. J., and Muchenje, V. (2013). Chemical composition, fatty acid content and antioxidant potential of meat from goats supplemented with Moringa (Moringa Oleifera) leaves, sun flower cake and grass hay. Meat Sci. 93, 455-462. doi: 10.1016/j.meatsci.2012.11.009

Ramin, M., and Huhtanen, P. (2013). Development of equations for predicting methane emissions from ruminants. J. Dairy Sci. 96, 2476-2493. doi: $10.3168 /$ jds.2012-6095

Roy, B. K., Bashar, M. K., Hossain, S. M. J., Huque, K. S., and Makkar, H. P. S. (2016). Performance evaluation of moringa oleifera and available roughages (Maize and Australian Sweet Jumbo) on Feeding Values of Growing BLRI Cattle Breed-1 (BCB-1) bulls. Am. J. Exp. Agric. 14, 1-9. doi: 10.9734/AJEA/2016/29284

Sánchez, N. R., Spörndly, E., and Ledin, I. (2006). Effect of feeding different levels of foliage of Moringa oleifera to creole dairy cows on intake, digestibility, milk production and composition. Livest. Sci. 101, 24-31. doi: 10.1016/j.livprodsci.2005.09.010

Soliva, C. R., Kreuzer, M., Foid, N., Foid, G., Machmüller, A., and Hess, H. D. (2005). Feeding value of whole and extracted Moringa oleifera leaves for ruminants and their effects on ruminal fermentation in vitro. Anim. Feed Sci. Technol. 118, 47-62. doi: 10.1016/j.anifeedsci.2004.10.005

$\mathrm{Su}, \mathrm{B}$., and Chen, X. (2020). Current status and potential of moringa oleifera leaf as an alternative protein source for animal feeds. Front. Veteri. Sci. 7:53. doi: $10.3389 /$ fvets.2020.00053

Subepang, S., Suzuki, T., Phonbumrung, T., and Sommart, K. (2019). Enteric methane emissions, energy partitioning, and energetic efficiency of zebu beef cattle fed total mixed ration silage. Asian-Aust. J. Anim. Sci. 32, 548-555. doi: 10.5713/ajas.18.0433

Susilawati, T. (2017). Spermatologi (In Indonesian). Malang: Universitas Brawijaya Press (UB Press).
Syarifuddin, N. A., Toleng, A. L., Rahardja, D. P., Ismartoyo, and Yusuf, M. (2017). Improving libido and sperm quality of bali bulls by supplementation of moringa oleifera leaves. Media Peternakan. 40, 88-93. doi: 10.5398/medpet.2017.40.2.88

Tamminga, S., Bannink, A., Dijkstra, J., and Zom, R. (2007). Feeding strategies to reduce methane loss in cattle. lelystad: the netherlands: animal nutrition and animal sciences group. Cambridge, MA: Wageningen UR, Report.

Van Soest, P. J., Robertson, J. B., and Lewis, B. A. (1991). Methods for dietary fibre, neutral detergent fibre, and nonstarch polysaccharides in relation to animal nutrition. J. Dairy Sci. 74, 3583-3597. doi: 10.3168/jds.S0022-0302(91)78 551-2

Wafa, W. M., El-Nagar, H. A., Gabr, A. A., and Rezk, M. M. (2017). Impact of dietary moringa oleifera leaves supplementation on semen characteristics, oxidative stress, physiological response and blood parameters of heat stressed buffalo bulls. J. Anim. Poultry Produc. 8, 367-379. doi: 10.21608/jappmu.2017.46008

Zeng, B., Luo, J., Wang, P., Yang, L., Chen, T., Sun, J., et al. (2019). The beneficial effects of Moringa oleifera leaf on reproductive performance in mice. Food Sci. Nutri. 7, 738-746. doi: 10.1002/fsn3.918

Zeng, B., Sun, J. J., Chen, T., Sun, B. L., He, Q., Chen, X. Y., et al. (2018). Effects of Moringa oleifera silage on milk yield, nutrient digestibility and serum biochemical indexes of lactating dairy cows. J. Anim. Physiol. Anim. Nutr. 102, 75-81. doi: 10.1111/jpn.12660

Conflict of Interest: The authors declare that the research was conducted in the absence of any commercial or financial relationships that could be construed as a potential conflict of interest.

Publisher's Note: All claims expressed in this article are solely those of the authors and do not necessarily represent those of their affiliated organizations, or those of the publisher, the editors and the reviewers. Any product that may be evaluated in this article, or claim that may be made by its manufacturer, is not guaranteed or endorsed by the publisher.

Copyright (C) 2021 Sultana, Das, Kabir, Deb and Islam. This is an open-access article distributed under the terms of the Creative Commons Attribution License (CC BY). The use, distribution or reproduction in other forums is permitted, provided the original author(s) and the copyright owner(s) are credited and that the original publication in this journal is cited, in accordance with accepted academic practice. No use, distribution or reproduction is permitted which does not comply with these terms. 